\title{
SMIIC Forum 2012
}

Organized by the Standards and Metrology Institute for Islamic Countries (SMIIC), a subsidiary organ of the Organization of Islamic Cooperation (OIC), this forum was held on November 6-9, 2012, at Turkey's Cornelia De Luxe Resort in Belek. The 160 delegates, who came from thirty-five countries, represented the National Standardisation Bodies (NSB), important national organizations of member countries, and such international organizations as the International Organisation for Standardisation (ISO), the International Electrotechnical Commission (IEC), the European Committee for Electrotechnical Standardisation (CENELEC), the Standardisation Organisation for the Cooperation Council for the Arab States of the Gulf (GSO), the Turkish Standards Institution (TSE), the Turkish Accreditation Agency (TURKAK), the Saudi Standards Metrology and Quality Organization (SASO), the Malaysian National Metrology Laboratory (SIRIM), the International Laboratory Accreditation Cooperation (ILAC), the OIC General Secretariat, the Commercial Cooperation of the Organization of Islamic Cooperation (COMCEC), the Statistical Economic and Social Research and Training Centre (SESRIC), and the Islamic Centre for the Development of Trade (ICDT).

Also present were media outlets, representatives of various government bodies, officers from the Presidency of Religious Affairs of the Republic of Turkey (DIYANET), and academics from significant international universities. One of the forum's main objectives was to create a platform to bring together experts and professionals from the fields of standardization, accreditation, and metrology in order to discuss these areas' current circumstances within OIC member countries and at the international level.

Hulusi Şentürk (chairman, Board of Directors of SMIIC; president, TSE) welcomed participants at the inaugural session and spoke of the importance of a standardization mechanism and the vital role standardization plays in economic development via the facilitation of international trade. Şentürk explained that standardization encourages quality production in manufacturing through competition and enables one to access a wide range of markets. Metin Eker (general director, COMCEC Coordination Office) highlighted the necessity of cooperation among OIC member countries to eradicate trade barriers and difficulties that hinder economic cooperation. He pointed out that the number of member countries has increased to twenty, now that Afghanistan (2008), Egypt (1999), and Lebanon (1999) have joined. 
The first working sessions began after the brief introduction of the OIC and SMIIC. Rob Steele (secretary general, ISO), alleged that member countries should, as the first and preferred option, consider adopting the relevant international standards when preparing new national standards or revising existing ones. James E. Matthews (vice-president, IEC) discussed IEC's safety and economic development side and the importance of standards in daily life. Tore Bloch Trondvold (president elect, CENELEC) pointed out that adopting a new comprehensive standard would engender unity among member countries, as has happened with the European Union (EU) member countries. Once a new European standard has been adopted by CEN or CENELEC, all members are obliged to adopt it and publish it at the national level as well, even those that did not vote for it. In addition, members must withdraw any national standards that are incompatible with the new standard.

Nabil A. Molla (secretary general, GSO) focused on the challenges faced by SMIIC members and how to accomplish harmonization through certain parameters, such as major export-import products, national standards strategies, and the exchange of standards development programs. Mehmet Cömert (director general, Ministry of Economy, Turkey) spoke on the standards' multilateral perspective. Saad al-Kasabi, (governor, SASO) emphasized the standards' impact on the economies of Muslim countries. Ramazan Usta (head, Standards Preparation Department, TSE) explained the Ottoman Standardization (Kanunname-i İhtisab-1 Bursa), which began as early as 1502 at the time of Sultan Bayazid Khan II (1447-1512).

The second group of working sessions, chaired by Saim Kayadibi (International Islamic University Malaysia [IIUM]), comprised Rob Steel, James E. Matthews, Tore Bloch Trondvold, Mohammed Saleh Badri (acting director-general, The Emirates Authority for Standardization \& Metrology United Arab Emirates [ESMA]), and Hüseyin Öztürk (director, International Standards Department, TSE). Badri talked on how modern technologies and demands have challenged traditional trade between countries and how standardization activities can affect and enhance trade between Islamic countries. Öztürk elaborated upon the TSE and standard preparation, adoption, and implementation activities. The first day's interesting talks and sessions were concluded with the evening's welcoming dinner to honor the participants.

The second day began with the third working session, which was chaired by Sinan Fank (coordinator, Mechanical Group, National Metrology Institute of Turkey [UME]). It featured Dae-Im Kang (president, Korea Research Institute of Standards and Science [KRISS]), Enver Sadikoğlu (quality manager, the European Association of National Metrology Institutes [EURAMET]), 
Sinan Fank, and Abdul Rahman bin Mohamed (head/principal metrologist, SIRIM). Kang outlined how metrology can bring sustainable economic growth. Sadikoğlu explored the main elements of technical barriers in trade and therefore the need for a quality infrastructure. He stressed that products must comply with the country's rules and regulations and that all imported and locally produced goods should be treated equally. Mohamed talked on the legal metrology system and the level of development of a country's national metrology infrastructure that would determine its capacity to trade and its integration into the wider global economy.

The second day's second session concluded with the fourth working session. In this session, Fawaz Allabadi (executive director, Jordan National Metrology Institute [JNMI]) focused on medical metrology. He stated that correct medical measurements for equipment in hospitals, medical centers, and medical labs lead to the right diagnosis and correct medical treatment, both of which improve the healthcare system and achieve the highest level of quality control to save patient lives and to reduce costs.

In the afternoon's fifth session, chaired by Mustafa Tayar (Veterinary Faculty, Uludağ University, Turkey), comprised Merih Malmqvist Nilsson (vicechair, ILAC), İrfan Aksoy (acting secretary general, TURKAK), and Heru Suseno (manager, Accreditation, National Accreditation Committee Indonesia [KAN]). Suseno analyzed consumers, manufacturers, and service providers, all of which have certain expectations about the quality, safety reliability, interoperability, efficiency, effectiveness, and environmental sustainability of products and services. In addition, he remarked that conformity assessment is often made obligatory by government regulations when public health, safety, or the environment may be at stake.

The forum's working sessions concluded with the sixth session, "Haläl Standards Accreditation Mechanism," moderated by Imtiaz Hossain (vicechancellor, Islamic University of Technology Bangladesh (IUT). Presenters were Saim Kayadibi (IIUM), Salih Yüksel (technical chief, TURKAK), Muhlis Akar (member, DIYANET), Mustafa Tayar (Veterinary Faculty, Uludağ University, Turkey), and Muhammed Sulaiman (director, Pakistan National Accreditation Council [PNAC]). Yüksel discussed the haläl certification, accreditation, and recognition process through the OIC and SMIIC regulations. He emphasized that a recertification application should be done at least six months before the expiry date of the current haläl certificate to ensure a smooth procedure. Tayar, who focused on religious, social, and ethical rules, said that globalization enables people to pay more attention to the importance of religious applications in commercial, social, and political realms. Therefore, food 
should be prepared according to the rules established by the Qur'an and Hadith literature and must be manufactured under hygenic conditions. As a result, haläl standards must be produced in order to solve the problems related to these issues.

The forum concluded with the participants' great desire to work toward improving the ummah and the world through the standardization and accreditation mechanism that the OIC could place on the world agenda in collaboration with other world standards and accreditation mechanisms. One of the forum's most significant outcomes could be said to be the sincerity of the participants, as well as the seriousness of the high-ranking officials of Turkey and the organizing committee members.

Saim Kayadibi Associate Professor, Faculty of Economics and Management Sciences Department of Economics International Islamic University Malaysia, Kuala Lumpur, Malaysia 